\section{CD44v6 expression in human skin keratinocytes as a possible mechanism for carcinogenesis associated with chronic arsenic exposure}

\author{
S. Huang,,,$^{1,2}$ S. Guo, ${ }^{2}$ F. Guo, ${ }^{3}$ Q. Yang, ${ }^{2}$ \\ X. Xiao, ${ }^{4}$ M. Murata, ${ }^{3}$ S. Ohnishi, ${ }^{1}$ \\ S. Kawanishi, ${ }^{1}$ N. Ma ${ }^{1}$ \\ ${ }^{1}$ Faculty of Health Science and Faculty \\ of Pharmaceutical Science, Suzuka \\ University of Medical Science, Japan; \\ ${ }^{2}$ School of Public Health, Guangxi Medical \\ University, Nanning, China; \\ ${ }^{3}$ Department of Environmental and \\ Molecular Medicine, Mie University \\ Graduate School of Medicine, Japan; \\ ${ }^{4}$ Department of Otorhinolaryngology, \\ Guangxi Medical University, Nanning, \\ China
}

\section{Abstract}

Inorganic arsenic is a well-known human skin carcinogen. Chronic arsenic exposure results in various types of human skin lesions, including squamous cell carcinoma (SCC). To investigate whether mutant stem cells participate in arsenic-associated carcinogenesis, we repeatedly exposed the human spontaneously immortalized skin keratinocytes (HaCaT) cell line to an environmentally relevant level of arsenic $(0.05 \mathrm{ppm})$ in vitro for 18 weeks. Following sodium arsenite administration, cell cycle, colony-forming efficiency (CFE), cell tumorigenicity, and expression of CD44v6, NF$\kappa \mathrm{B}$ and $\mathrm{p} 53$, were analyzed at different time points $(0,5,10,15,20,25$ and 30 passages). We found that a chronic exposure of HaCaT cells to a low level of arsenic induced a cancer stem-like phenotype. Furthermore, arsenictreated $\mathrm{HaCaT}$ cells also became tumorigenic in nude mice, their growth cycle was predominantly in G2/M and S phases. Relative to nontreated cells, they exhibited a higher growth rate and a significant increase in CFE. Western blot analysis found that arsenic was capable of increasing cell proliferation and sprouting of cancer stem-like phenotype. Additionally, immunohistochemical analysis demonstrated that CD44v6 expression was upregulated in $\mathrm{HaCaT}$ cells exposed to a low level of arsenic during early stages of induction. The expression of CD44v6 in arsenic-treated cells was positively correlated with their cloning efficiency in soft agar ( $\mathrm{r}=0.949, \mathrm{P}=0.01)$. Likewise, the expressions of activating transcription factor NF- $\mathrm{BB}$ and p53 genes in the arsenic-treated $\mathrm{HaCaT}$ cells were significantly higher than that in non-treated cells. Higher expressions of CD44v6, NF- $\mathrm{B}$ and $\mathrm{p} 53$ were also observed in tumor tissues isolated from $\mathrm{Balb} / \mathrm{c}$ nude mice. The present results suggest that CD44v6 may be a biomarker of arsenicinduced neoplastic transformation in human skin cells, and that arsenic promotes malignant transformation in human skin lesions through a NF- $\mathrm{KB}$ signaling pathway-stimulated expression of CD44v6.

\section{Introduction}

Arsenic has been recognized as a Class 1 carcinogen by the International Agency for Research on Cancer in 2004. ${ }^{1}$ Epidemiological researches indicate that individuals exposed to arsenic are at a higher risk for developing skin, liver, and bladder cancers. ${ }^{2-7}$ The skin is a major target of arsenic exposure and one of the most sensitive tissues to chronic arsenic exposure. Chronic exposure to arsenic results in various epidermal alterations, including hyperpigmentation, hyperkeratosis, squamous cell carcinoma (SCC) and basal cell carcinoma. Although inorganic arsenic alone does not seem to independently induce skin cancer in animals, it definitely acts together with UV irradiation to stimulate skin cancer in mouse. ${ }^{8,9}$ Nevertheless, there is still a lack of specific molecular biomarkers to detect arsenic-induced early malignant lesions. Increasing recent evidence indicates that can cers may develop from a small subpopulation of cancer stem cells (CSCs) present in both solid tumors and hematological malignancies. ${ }^{10-14}$ Analysis of biomarker expression during tumor formation may help to gain a better insight into the process of tumorigenesis and to identify new markers for early diagnosis of squamous cell malignant transformation. ${ }^{14-17}$ The CSCs biomarkers can be identified by the expression of a variety of cell surface markers, including CD133 and CD44, some of which have phenotypic significance ${ }^{18}$ and show higher expression of a variety of stem cell maintenance-related genes, including 0ct-4, p63 and Notch. ${ }^{10,14,19}$

CD44 is the receptor for hyaluronic acid (HA). It mediates cell to cell and cell matrix interactions through its affinity for HA. CD44 plays an important role in cell migration, tumor growth and progression, lymphocyte activation recirculation and homing, and hematopoiesis. ${ }^{20-23}$ CD44 receptor (CD44R) represents a heterogeneous group of $\mathrm{CD} 44$ variant isoforms expressed constitutively in epithelial cells and monocyte lineage cells and can be up-regulated in activated leukocytes. CD44R and, in particular, CD44v6 isoforms may be involved in leukocyte attachment to and rolling on endothelial cells, homing to peripheral lymphoid organs and to sites of inflammation. The role of CD44v6 in tumor
Correspondence: Prof. Ning Ma, Faculty of Health Science and Faculty of Pharmaceutical Science, Suzuka University of Medical Science, Suzuka, Mie 510-0293, Japan.

Tel. + 81.593838991 - Fax: +81.593839666

E-mail:maning@suzuka-u.ac.jp

Prof. Songchao Guo, School of Public Health Guangxi Medical University, Nanning 530021,

China. E-mail: scguo54@yahoo.com.cn

Key words: arsenic, human skin keratinocytes, malignant transformation, cell surface markers, CD44v6.

Acknowledgments: this work was partly supported by a Grant-in-Aid for Scientific Research from the Ministry of Education, Culture, Sports, Science, and Technology of Japan.

Contributions: $\mathrm{SH}$, cell culture, cell cycle analysis, soft agar colony assay, mouse tumor models, Western blot analysis; SG, animal experiment; FG, cell culture, immunohistochemical study; QY, SO, cell culture, Western blot analysis, cell cycle analysis; XX, cell culture; MM, statistical analysis; SK, immunohistochemical study; NM, soft agar colony assay, immunohistochemical study, statistical analysis.

Received for publication: 23 August 2012. Accepted for publication: 1 0ctober 2012.

This work is licensed under a Creative Commons Attribution NonCommercial 3.0 License (CC BYNC 3.0).

CCopyright S. Huang et al., 2013

Licensee PAGEPress, Italy

European Journal of Histochemistry 2013; 57:e1 doi:10.4081/ejh.2013.e1

metastasis has been attributed to an ability to confer metastatic potential to nonmetastatic cell lines, ${ }^{21,24,25}$ leading to tumor progression and metastasis in human cancers. ${ }^{26,27}$ Expression of CD44v6 has been found to correlate significantly with lymphatic and/or hematogenous metastasis. ${ }^{28}$

Arsenic is a well-documented carcinogen that also appears to be a valuable therapeutic tool in cancer treatment. ${ }^{29}$ Arsenic trioxide $\left(\mathrm{As}_{2} \mathrm{O}_{3}\right)$ was shown to inhibit tumor metastasis by reducing the expression of metastasis-related genes, including CD44v6; ${ }^{30-33}$ but arsenic cytotoxicity is dependent on the degree of exposure, and presentation of pleiotropic cellular effects. ${ }^{34-37}$ Long-term arsenic exposure has been reported to cause a malignant transformation of human keratinocytes in vitro. ${ }^{38}$ Some growth factors that stimulate-melanoma cells can increase the expression of CD44v6 and promote motility in primary human melanocytes through CD44v6 via a NF-кB/Egr-1/C/EBP-beta complex. ${ }^{39}$ However, there are no reports on growth properties and on CSCs biomarker expression profile in human skin epithelial cell lines exposed to arsenic. In order to investigate 
the mechanisms of arsenic-induced carcinogenesis, we exposed human spontaneously immortalized skin keratinocytes (HaCaT) to an environmentally relevant level of arsenic in vitro, determined the acquired cancer phenotype and performed immunocytochemical and Western blot (WB) analysis.

\section{Materials and Methods}

\section{Chemicals and antibodies}

Sodium arsenite $\left(\mathrm{NaAsO}_{2} ; 99.99 \%\right.$ pure $)$ was obtained from Sigma Chemical Co. (St. Louis, MO, USA). The CycleTESTTM PLUS DNA Reagent Kit, mouse monoclonal anti CD44v6, anti CD133, anti p53 and anti NF- $\kappa$ B were purchased from Santa Cruz Biotechnology, Inc., Santa Cruz, CA, USA.

\section{Cell culture}

The $\mathrm{HaCaT}$ cell line was originally derived from normal human adult skin, and is nontumorigenic. ${ }^{40}$ The cells were cultured in Dulbecco's Modified Eagle's Medium (DMEM) supplemented with $10 \%$ fetal bovine serum (FBS), and antibiotics (100 U/mL penicillin and $100 \mu \mathrm{g} / \mathrm{mL}$ streptomycin). Cultures were maintained at $37^{\circ} \mathrm{C}$ and in a humidified $5 \%$ $\mathrm{CO}_{2}$ atmosphere. For chronic exposure, cells were maintained continuously in a medium containing $0.05 \mathrm{ppm}$ of $\mathrm{NaAsO}_{2}$ for 30 passages (about 18 weeks). Arsenic-treated and nontreated (control) cells for the experiments were selected every 5 passages (about 3 weeks).

\section{Cell cycle analysis}

After the cells grew to $90-95 \%$ confluence, they were harvested by gentle trypsinization, washed with cold PBS (calcium and magnesium free), and collected by centrifugation. For cell cycle analysis, $\sim 10^{6}$ cells were resuspended in $1 \mathrm{~mL}$ phosphate buffered saline (PBS) pH 7.4 and fixed in $75 \%$ ice-cold ethanol with $24 \mathrm{~h}$ incubation at $-20^{\circ} \mathrm{C}$. After a brief centrifugation, cells were washed once with PBS and incubated for $30 \mathrm{~min}$ at $37^{\circ} \mathrm{C}$ in PBS containing $40 \mu \mathrm{g} / \mathrm{mL}$ propidium iodide and $100 \mathrm{U}$ RNase. For each tube, 20,000 cells were immediately measured on a FACSCalibur ${ }^{\mathrm{TM}}$ flow cytometer using CellQuest Pro Software (BD Company, Franklin Lakes, NJ, USA).

\section{Soft agar colony assay}

We assessed colony forming efficiency (CFE) in soft agar every 5 passages ( 3 weeks to ascertain) acquired malignant phenotype. Cells were subcultured and passed through a $40 \mu \mathrm{m}$ cell strainer (BD Biosciences, San Jose, CA, USA) to get a single cell suspension. Plates were pre- pared by adding $2 \mathrm{~mL}$ of agar medium $(0.8 \mathrm{~mL}$ of $1.25 \%$ agar and $1.2 \mathrm{~mL}$ of DMEM with $10 \%$ FBS and 10\% DPBS) to each plate. HaCaT cells (12,500 cells/35 mm plate) were suspended in 1 mL DMEM with 10\% FBS and $0.33 \%$ agar and layered on top of the hardened agar medium. Plates were maintained at $37^{\circ} \mathrm{C}$ for 19 days. Colonies were then counted using an automated colony counter. Only colonies over $0.5 \mathrm{~mm}$ in diameter were counted as positive.
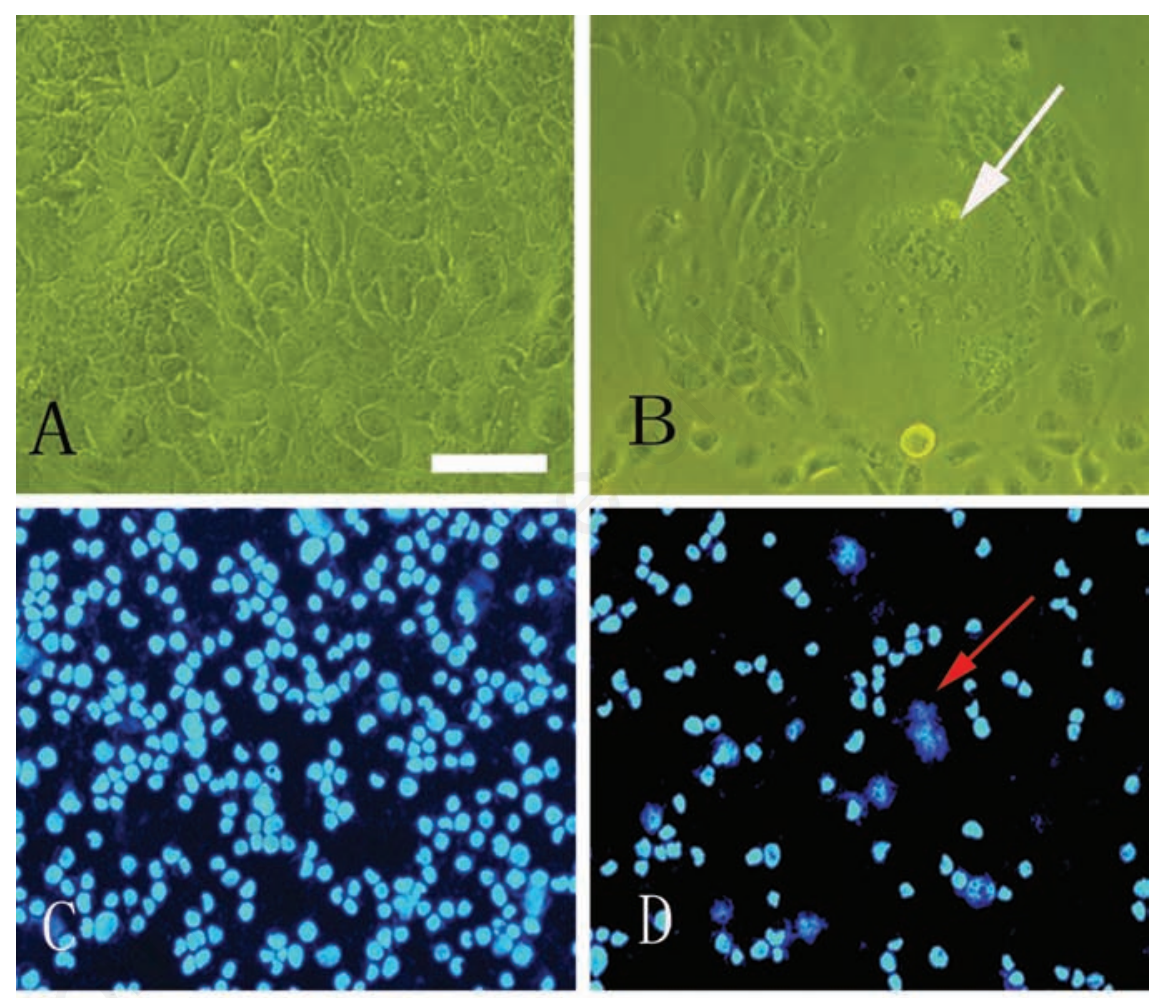

$\mathrm{E}$

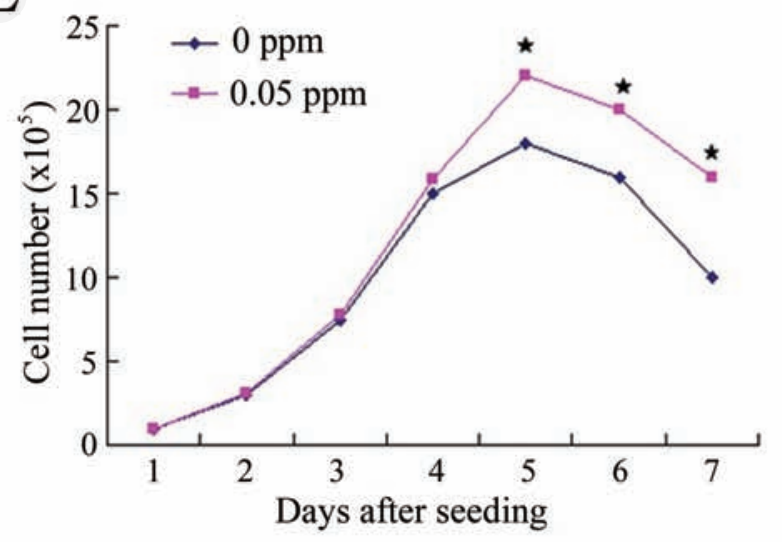

Figure 1. Low-level, chronic arsenic exposure induced malignant transformation in HaCaT cells. A) Control cells maintained an epithelial-like morphology at 25 passages stage. B) Arsenic-treated cells exhibited morphological alterations with the frequent occurrence of giant multinuclear cells at 25 passages stage. C) Control $\mathrm{HaCaT}$ cells and D) arsenic-treated cells at 25 passages stage stained with DAPI. Arrows indicate giant multinuclear cells. E) Growth curves in control and arsenite-treated $\mathrm{HaCaT}$ cells (means $\pm \mathrm{SD}, \mathrm{n}=3$ ). Cells treated by sodium arsenite 25 generations, grown in $100 \mathrm{~mm}$ dish and calculated the number of cells in different days by cell counter. Five days later, arsenitetreated $\mathrm{HaCaT}$ cells have more vigorous growth capacity compare to passage control cells. ${ }^{*} \mathbf{P}<0.05$ difference from passage control cells. Scale bar: $40 \mu \mathrm{m}$. 
$\mathrm{mL}$ ) were injected subcutaneously on the left axillary fossa of the mice. The formation of subcutaneous tumors was monitored and measured with a digital calliper.

The tumor volume (V) was calculated based on the formula

$$
\mathrm{V}=\mathrm{L} \times \mathrm{W}^{2} \times 0.5
$$

where $\mathrm{L}$ is the length and $\mathrm{W}$ is the shortest width of the tumor.

Animals were observed for tumor formation over a 6-month period. All procedures carried out in animals were conducted in compliance with the policies and regulations of Guangxi Medical University Institutional Animal Care and Use Committee (Nanning, China). During the 6-month observation period, no tumors occurred in mice inoculated with untreated HaCaT ells, whereas tumor incidence was over $75 \%$ after inoculation with arsenic-treated cells.

\section{Western blotting analysis}

After washing three times with ice-cold PBS, whole cell extracts were obtained using Cell Lysis Buffer (Cell Signaling Technology, Inc., Beverly, MA, USA) with 0.5\% Protease Inhibitor Cocktail (Sigma) and 1\% PMDF. Protein fractions were stored at $-70^{\circ} \mathrm{C}$ until use. Protein concentrations were determined by Bio-Rad protein assay (Bio-Rad, Hercules, CA, USA) with bovine serum albumin (BSA) as a standard. Proteins were separated by Novex 12\% Nupage Gel (Invitrogen, Carlsbad, CA, USA) and transferred onto nitrocellulose membranes. The blots were probed with the primary antibodies (1:400), followed by incubation with horseradish peroxidase-conjugated secondary antibodies. Antibody incubations were carried out in BlockerTM BLOTTO in TBS (Pierce, Rockford, IL, USA). Immunoreactive proteins were detected by chemiluminescence using ECL reagent (Amersham Pharmacia, Piscataway, NJ, USA) and subsequent autoradiography. Quantitation of the results was carried out by Bio-Rad Gel Doc 2000 Systems with Bio-Rad TDS Quantity One software. After the blots were stripped using Restore Western Blot Stripping Buffer (Pierce), they were probed for $\beta$-actin (Cell Signaling Technology, Inc.), which was used as the loading control.

\section{Pathological sample preparation and immunohistochemical study}

Antibody immunoreactivity in the cells and tumor were assessed by immunofluorescence labeling study as described previously. ${ }^{41}$ $\mathrm{HaCaT}$ cells that had been incubated with arsenic on culture slides (BD Falcon, Franklin Lakes, NJ, USA) were fixed with $4 \%$ formaldehyde in PBS for 10 min at room temperature and washed with PBS three times. The cells
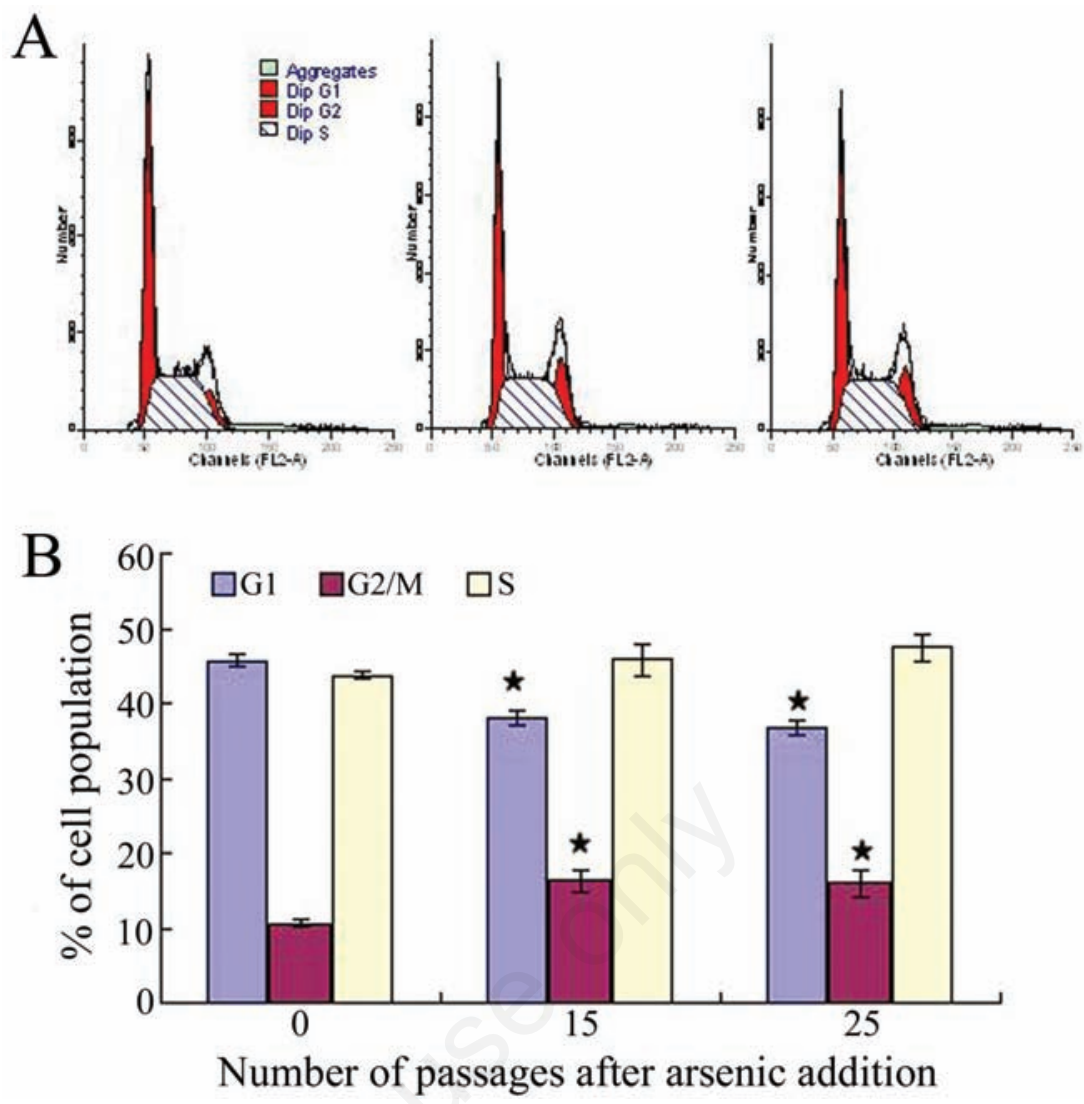

Figure 2. A) Flow cytometric analysis of the cell cycle distribution of cultured $\mathrm{HaCaT}$ cells with PI staining. B) Bar chart presentations of the $\mathrm{HaCaT}$ cells cycle distribution under the influence of arsenic. The values shown the mean \pm SEM, with $n=3 .{ }^{*} P<0.05$ when compared with the passage control.

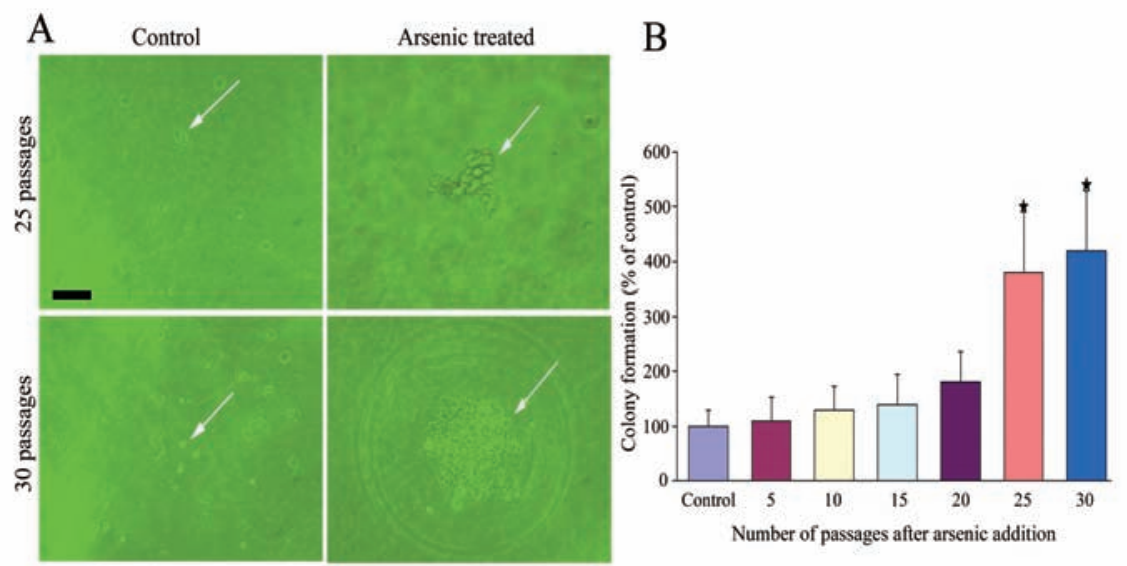

Figure 3. Colony formation was measured by soft agar colony assay in arsenic-treated cells and passage-matched control cells. A) None colony formation in passage-matched control cells (25 passages, 30 passages) (left), but there were colony formations produced by arsenic-treated cells in $\mathbf{2 5}$ passage and in $\mathbf{3 0}$ passage (right). Arrows indicate colony formations. B) The incidence of colony formation was increased during arsenic exposure period, 30 passages (18 weeks) of arsenic exposure was 4.2 -fold higher in the arsenictreated cells than in passage-matched control cells; numerical data represent mean and $\mathbf{9 5 \%} \mathrm{CI}(\mathrm{n}=3) .{ }^{*} \mathbf{P}<\mathbf{0 . 0 5}$ compared with control. Scale bar: $40 \mu \mathrm{m}$. 
were treated with $0.5 \%$ Triton X-100 for 3 min and then incubated with $1 \%$ skim milk for 30 min at room temperature. To detect CD44v6, the cells were incubated with mouse monoclonal anti-CD44v6 antibody $(0.5 \mu \mathrm{g} / \mathrm{mL}$, abcam, Tokyo, Japan) overnight at room temperature. To detect CD133, NF-кB and p53, CD133 rabbit polyclonal antibody (1:600, Abcam, Tokyo, Japan), NF-кB monoclonal antibody (1:400, Santa Cruz Biotechnology, Inc., Santa Cruz, CA, USA) and p53 monoclonal antibody (1:400, Calbiochem, Darmstadt, Germany) were used instead. Then the cells were incubated with fluoresenct secondary antibody Alexa 594-labeled goat antibody against rabbit IgG or Alexa 488-labeled goat antibody against mouse IgG (1:400, Molecular Probes, Eugene, OR, USA) for $3 \mathrm{~h}$. The nuclei were stained with DAPI (Dapi FluoromountG ${ }^{\text {TM }}$, Birmingham, AL, USA). The stained cells were examined under a florescent (BX53, Olympus, Tokyo, Japan). The staining intensity per cell of CD44v6, NF-кB and p53 were evaluated by analyzing three separate fields containing approximately 800 cells in average for each sample with Image $\mathbf{J}$ software. To confirm the immunoreactive specificity of primary antibody, the cells were incubated with omission of primary antibodies. Then, the cells were incubated with Alexa 594-labeled or Alexa 488-labeled secondary antibody and examined as described above.

\section{Statistical analysis}

Data are expressed as mean \pm SEM of 3-6 determinations. Analysis of variance (ANOVA) followed by Dunnett's multiple comparison tests were performed for comparisons between treatment groups and corresponding controls. The level of significance was set at $\mathrm{P} \leq 0.05$ in all cases.

\section{Results}

\section{Chronic arsenic exposure of $\mathrm{HaCaT}$ cells induced cancer stem-like phenotype}

After 25 passages of exposure to $0.05 \mathrm{ppm}$ of arsenic, morphological differences were observed between the arsenic-treated $\mathrm{HaCaT}$ cells and passage-matched control cells. Whereas control cells maintained an epithelial-like morphology, arsenic-treated cells developed into giant multinuclear cells, and exhibited a more vigorous growth capacity (Figure 1). The changes in the cell cycle showed that the majority of cells were in G2 and $S$ phase (Figure 2). These data clearly demonstrate that arsenic can induce genomic instability and cell cycles changes. The soft agar colony assay is a useful method to iden- tify malignantly transformed cells in vitro. The incidence of colony formation was increased during arsenic exposure period, which after 30 passages of arsenic exposure was 4.2 -fold higher in the arsenic-treated cells than in passage-matched control cells (Figure 3). Together, these characteristics show that arsenic-treated HaCaT cells rapidly acquired a cancer phenotype upon an exposure to arsenite. To establish malignant transformation, arsenic-treated 25 passages cells $\left(2 \times 10^{6} / 0.2 \mathrm{~mL}\right)$ were injected subcutaneously on the left axillary fossa of Balb/c nude mice. Arsenite-treated cells rapidly developed into highly pleomorphic tumors, with regional invasion. The skin tumors were highly undifferentiated, highly malignant, and composed of immature epithelial- and mesenchymal-like cells, and were identified as SCC (Figure 4). Thus, the cells present after 25 passages of arsenic exposure represent a malignant transformation.

\section{CD44v6 expression in arsenic-treated $\mathrm{HaCaT}$ cells}

The levels of CD44v6 and CD133 proteins of HaCaT cells exposed to 0.05 ppm of arsenic were analyzed at different post-exposure times by WB and immunofluorescence histochemistry. Figure 5A,B show that CD44v6 protein was increased to a significant extent in the arsenic-treated group from 25 passages relative to $\mathrm{HaCaT}$ cells in the $0 \mathrm{ppm}$ arsenic group. Immunohistochemistry showed that CD44v6 strongly stained in the cell membrane, of arsenic-treated $\mathrm{HaCaT}$ cells after 20 and 25 passages, with control cells and arsenic-treated $\mathrm{HaCaT}$ before 20 passages showing either no or weak immunoreactivity (Figure 5C). In arsenic-treated group, quantitative analysis of CD44v6 immunoreactive HaCaT cells showed that, in the average, the immunoreactivity increased proportionally to the number of passages from 15 to 25 passages. A long term exposure of $\mathrm{HaCaT}$ cells to arsenic caused the activity of CD44v6 to increase with an increase in the duration of the exposure (Figure 5D), that the extent of CD44v6 immunoreactivity in arsenic-treated cells was found to positively correlate with the cloning efficiency in soft agar $(r=0.949$, $\mathrm{P}=0.01)$. On the other hand, little or no immunoreactivity was for CD133 was observed in arsenic-treated cells, and no immunoreactivity was observed in passagematched control cells (data not shown).
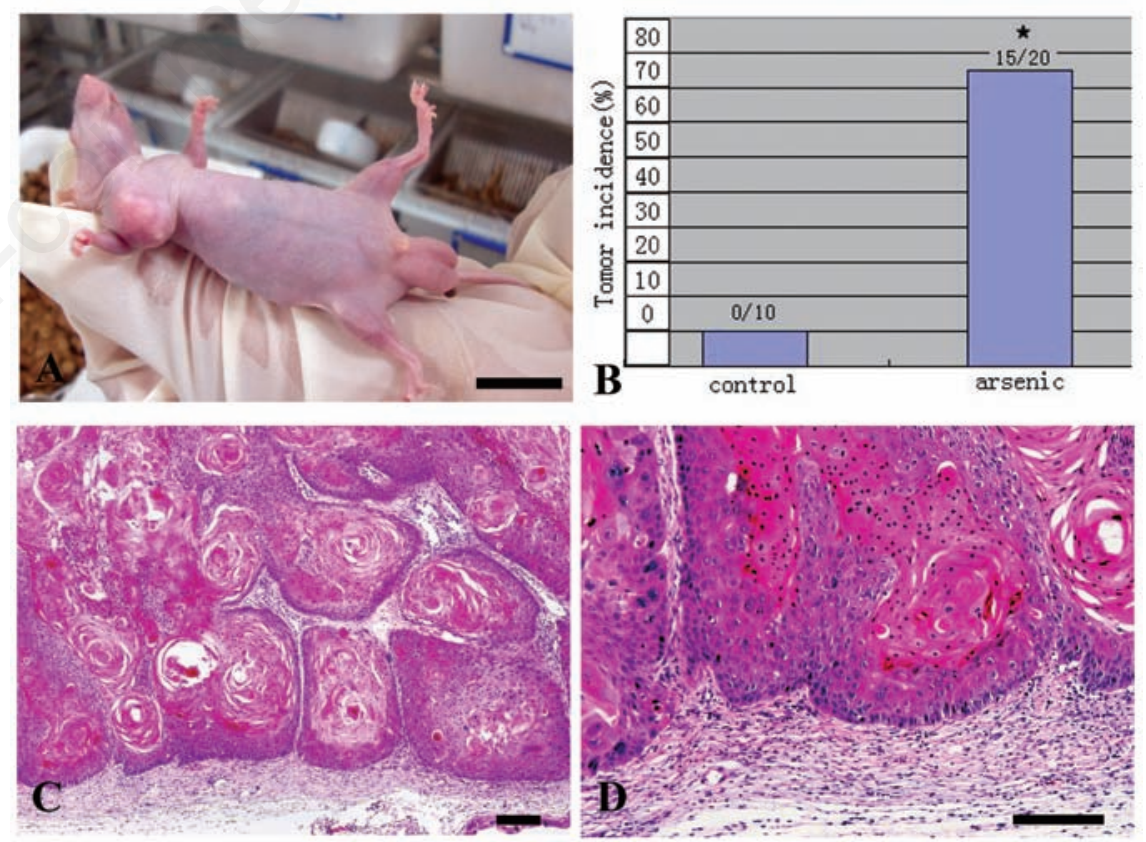

Figure 4. Arsenic-treated 25 passages cells $\left(2 \times 10^{6} / 0.2 \mathrm{~mL}\right)$ were injected subcutaneously on the left axillary fossa of $\mathrm{Balb} / \mathrm{c}$ nude mice. A) Arsenic-treated $\mathrm{HaCaT}$ cells became apparently tumorigenic in nude mice. Scale bar: $10 \mathrm{~mm}$. B) Tumor incidence after inoculation under the subcutaneous of axillary fossa with control $(n=10)$ and arsenite-treated cells (25 passages) $(n=20)$. C,D) Pathological studies of Xenograft tumor sections showed a highly undifferentiated, pleomorphic nature of tumors from arsenic-treated $\mathrm{HaCaT}$ cells, and the tumor testified as squamous cell carcinomas (SCC), a type of cancer that induced by arsenic in skin. Scale bars: $100 \mu \mathrm{m}$. 
A

\section{Passages \\ CD44v6 \\ actin}
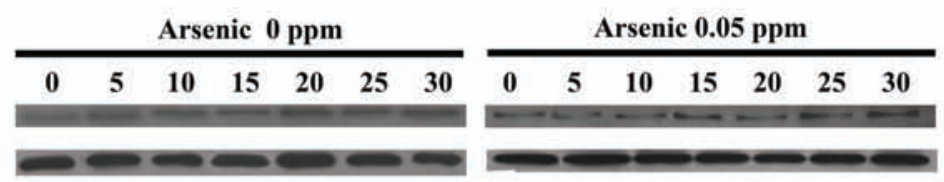

B

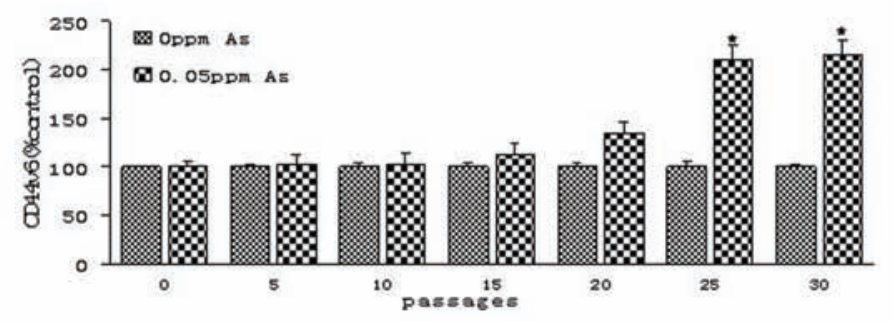

C
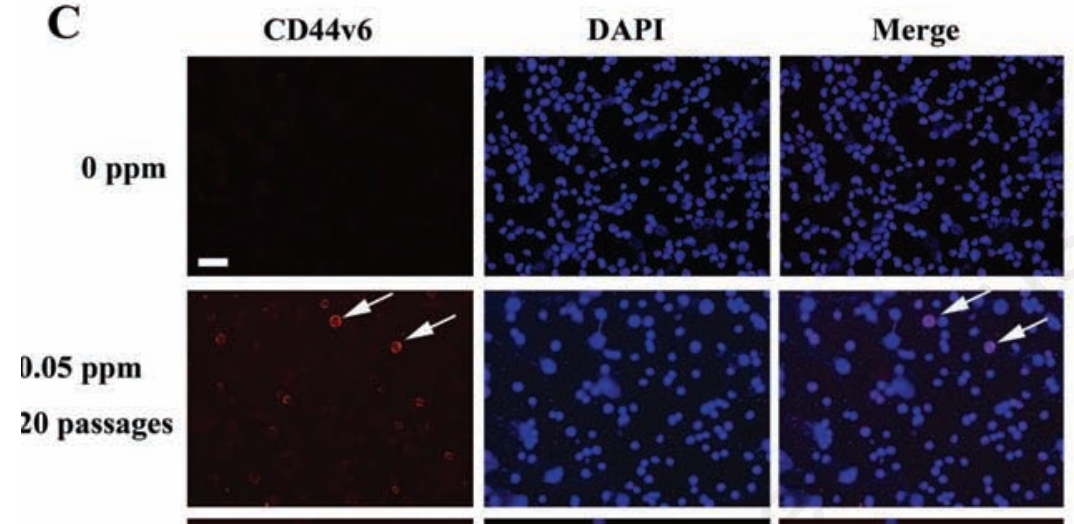

$0.05 \mathrm{ppm}$

25 passages
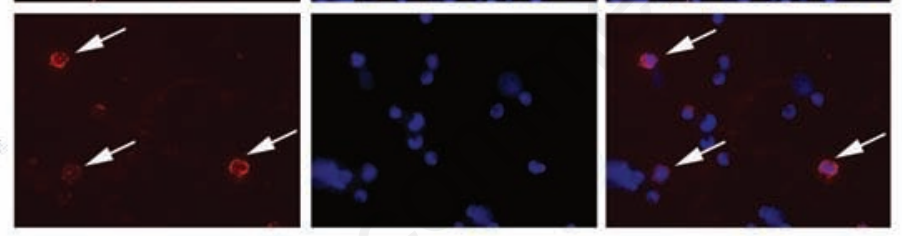

D

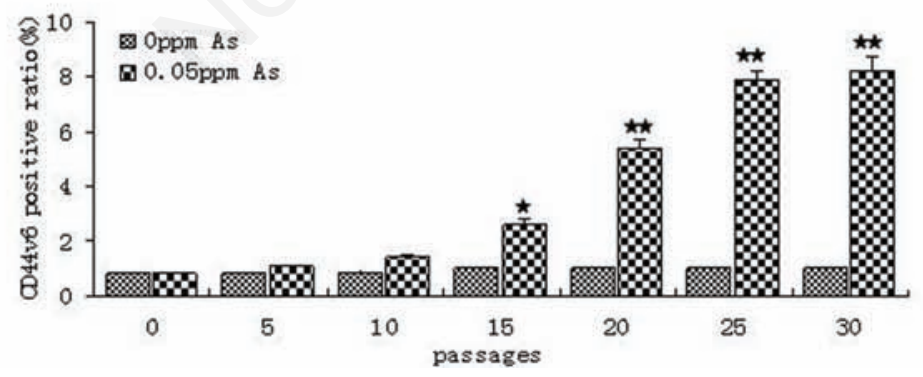

Figure 5. CD44v6 immunoreactivity is localized in arsenic-treated cells. $\mathrm{HaCaT}$ cells were exposed to $0.0 \mathrm{ppm}$ or $0.05 \mathrm{ppm}$ sodium arsenite for 30 passages (about 18 weeks). A) Western blot analyses of $\mathrm{CD} 44 \mathrm{v6}$ levels; $\mathrm{HaCaT}$ cells were exposed to $0.0 \mathrm{ppm}$ or 0.05 ppm of arsenite for 5, 10, 15, 20, 25 or 30 passages; densities of bands were quantified by Quantity One software; $\beta$-actin level measured in parallel, served as controls. B) Protein levels of $\mathrm{CD} 44 \mathrm{v} 6$ (mean $\pm \mathrm{SD}, \mathrm{n}=3$ ). ${ }^{*} \mathrm{P}<0.01$ difference from passage-matched control cells. C) CD44v6 expression in arsenic-treated cells and passage-matched control cells (20, 25 passages), CD44v6 immunoreactivity positive cells localized primarily in the membrane of some $\mathrm{HaCaT}$ cells. D) $\mathrm{CD} 44 \mathrm{v} 6$ positive ratio of $\mathrm{CD} 44 \mathrm{v} 6$ immunoreactivity positive cells in arsenic-treated cells and passage-matched control cells is $7.9 \%$ at 25 passages of arsenic-treated cells. ${ }^{* *} \mathrm{P}<0.01$ difference from passage-matched control cells. Scale bar: $40 \mu \mathrm{m}$.
High expression of CD44v6 in xenograft tumors from arsenictransformed $\mathrm{HaCaT}$ cells

The expression of CD44v6 in HaCaT cells transplanted from nude mouse tumor tissue was examined by immunohistochemistry. While the expression of CD44v6 in the area surrounding the tumor tissue was nil, a strong membranous staining was found in more than $50 \%$ of tumor cells (Figure 6).

\section{Alterations of P53 and NF-кB gene expression with arsenic treatment}

We examined the expression of transcription factor NF- $\kappa \mathrm{B}$ and tumor suppressor gene p53 during arsenic-induced HaCaT cells malignant transformation. As shown in Figure 7, growth of HaCaT cells in 0.05 ppm arsenic for 15 passages or more resulted in a significant increase of NF- $\mathrm{B}$ protein; and in a variable expression of $\mathrm{p} 53$ gene, which was first lost and then reactivated by the arsenicinduced malignant transformation. The NF$\kappa \mathrm{B}$ and p53 protein, which was mainly stained in the nucleus, were observed in cancer cells, but not in normal cells (Figure 8). While the detection rate of NF- $\mathrm{KB}$ protein in 0 passage $\mathrm{HaCaT}$ cells was $22.65 \%$, it was $42.27 \%$ in $0.05 \mathrm{ppm}$ arsenic-treated HaCaT cells for 15 passages or more $(\mathrm{P}<0.05)$.

\section{Discussion}

Arsenic is one the most toxic metals present in the natural environment. ${ }^{42}$ The extent of arsenic poisoning depends on various factors such as its dose, an individual's susceptibility to it and the age of the affected individual. Its cytotoxicity is dependent on the extent of exposure, and presentation of pleiotropic cellular effects. ${ }^{34-37}$ Consistent with the biphasic dose response of environmental agents, a low level of arsenic usually leads to stimulation of cell proliferation and a high one is often cytotoxic. ${ }^{35} \mathrm{~A}$ previous research has shown that chronic exposure to low concentrations of arsenite $(<5 \mu \mathrm{M})$ leads to neoplastic transformation..$^{38}$ In our study, HaCaT cells exposed to $0.05 \mathrm{ppm}$ arsenite for 30 passages (about 18 weeks) were identified as malignant by their anchorage-independent growth and became tumorigenic in the nude mouse. In addition, arsenic was found to induce morphological changes, exemplified by the occurrence of giant multinuclear cells, and cell cycle changes.

Arsenic has been shown to increase mRNA transcripts of growth factors including granulocyte-macrophage colony stimulating factor, transforming growth factor- $\alpha$ and the inflam- 
matory cytokine-like tumor necrosis factor$\alpha .{ }^{43,44}$ Continuously exposure of the human prostate epithelial stem/progenitor cell line WPE-stem to an environmentally relevant level of arsenic $(5 \mu \mathrm{M})$ in vitro led to the acquisition of cancer phenotype, suppression of self-renewal gene (p63, BMI-1, ABCG2, SHH, OCT-4, and NOTCH-1), and reactivation during acquired cancer stem cells like phenotype. ${ }^{38}$ High concentration of $\mathrm{As}_{2} \mathrm{O}_{3}$ has been shown to inhibit tumor metastasis by reducing the expression of metastasis-related genes, including CD44v6. ${ }^{33-36}$ However, there are no reports describing the expression of CD44v6 in cells and tumor as a result of a long-term treatment with a low $(0.05 \mathrm{ppm})$ level of arsenic. In agreement with this finding, we have verified that $\operatorname{CD} 44 \mathrm{v} 6$ was expressed in HaCaT cells subjected to a longterm treatment with a low level of arsenic. Moreover, the expression of CD44v6 in arsenic-treated cells was in good agreement with the cloning efficiency in soft agar $(\mathrm{r}=0.949, \mathrm{P}=0.01)$. The expression of a cell adhesion molecule such as CD44v6 has been shown to be associated with metastasis and poor prognosis in human malignancies such as breast cancer and colorectal cancer, ${ }^{45,46}$ and increased levels of CD44 and/or different patterns of splice variants have been found in tumors but not in their normal counterparts. ${ }^{47,48}$ More significantly, in our study we found that CD44v6 was an independent prognostic biological marker for colony formation of arsenic-treated cells in soft agar, that the strong expression of $\mathrm{CD} 44 \mathrm{v} 6$ in arsenicinduced tumor cells will make this metastasis gene a valuable molecular marker for various human skin lesions, including squamous cell carcinoma (SCC), resulting from a chronic exposure to arsenic.

In target cells, carcinogenesis is a multiplestep process, involving serial genetic modifications that lead to alterations in growth control and, consequently, in the formation of malignancies. ${ }^{49,50}$ In the present study, alteration of the expression of p53 preceded the activation of CD44v6 which, in turn, was followed by the activation of NF- $\kappa \mathrm{B}$, significant cell cycle changes, and uncontrolled cell growth. Hence, it is evident that arsenic can induce genomic instability and initiate cell signal transduction by a number of ways, to cause transcription factor activation, and to induce a series of regulating cell differentiation and tumor-related gene expression events.

People carrying one altered p53 gene in their germline have a high probability of developing a tumor. ${ }^{51,52}$ Most human cancers result from either mutation in the p53 gene, to generate a dysfunctional or nonexpressed protein, or the altered expression of other gene products that disrupt p53 functions. ${ }^{53,54}$ Since our study showed that a low (0.05 ppm)
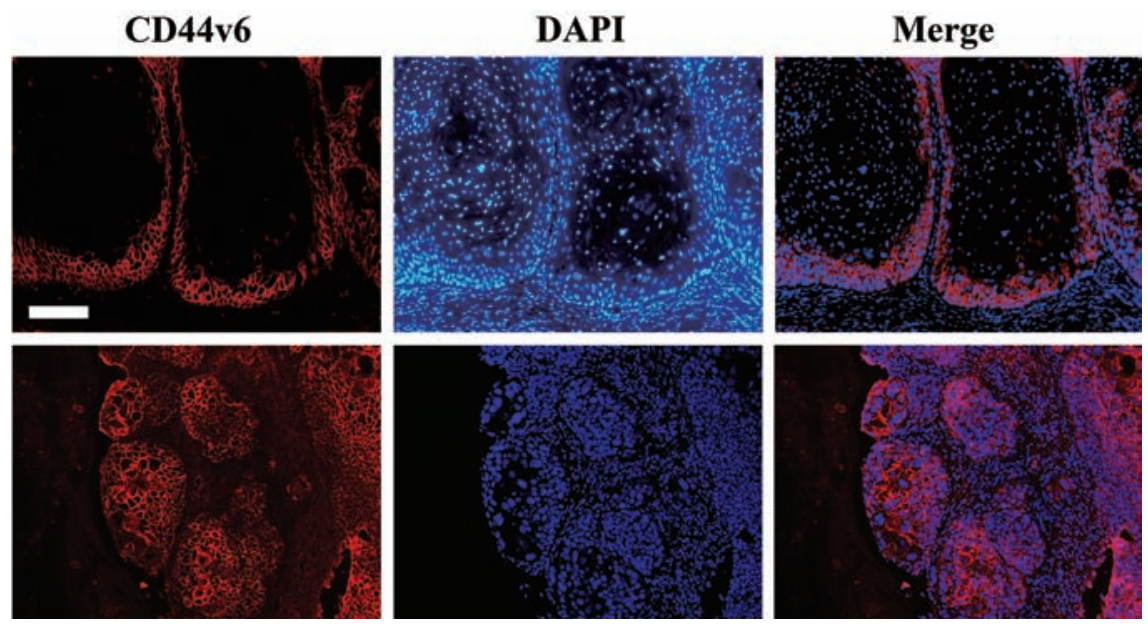

Figure 6. CD44v6 expression in tumor cells of Xenograft tumor. CD44v6 expression was estimated by the percentage of tumor cell membrane staining, exceed $50 \%$ tumor cells were CD44v6 immunoreactivity positive. Scale bar: $100 \mu \mathrm{m}$.
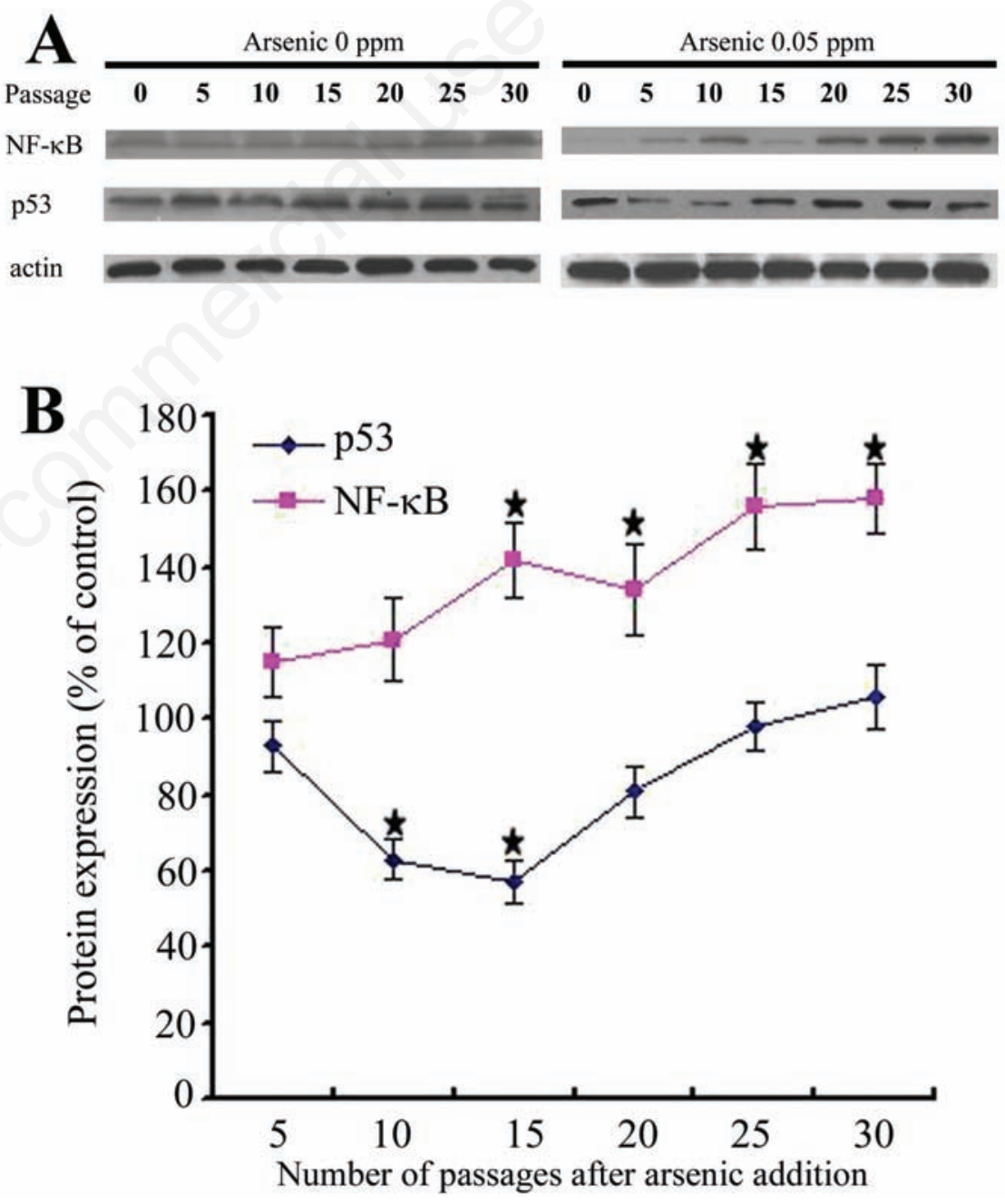

Figure 7. A) Western blot analyses of NF- $\mathrm{KB}, \mathrm{p} 53$ levels in the arsenic-treated $\mathrm{HaCaT}$ cell. Densities of bands were quantified by Quantity One software. $\beta$-actin levels, measured in parallel, served as controls. B) Protein levels of p53 and NF- $\mathrm{kB}$ (means \pm SD, n=3). ${ }^{*} \mathbf{P}<0.05$ difference from passage-marched control cells. 
level of sodium arsenite was able to induce the proliferation of HaCaT cells but not apoptosis, it is conceivable that arsenite may be inactivating p53 function. Our results show that in HaCaT cells exposed to arsenite there was an initial decline in the protein level of p53 which was subsequently recovered when the cells underwent malignant transformation.

The p53 gene is involved in the maintenance of genome stability. In response to diverse cellular stresses, the p53 protein transactivates downstream target genes required for DNA repair, cell cycle arrest, and apoptosis to raise a barrier to tumor progression. ${ }^{55,56}$ There are many mechanisms for break of this barrier, general presume, most notably by p 53 mutations that impair the DNA damage response pathway, allows cancers to develop..$^{54}$ However, arsenic does not induce carcinogenesis via a classic mutagenic mechanism. ${ }^{42}$ So, molecular factors may be involved in the inactivation of p53 function induced by low concentrations of arsenite. It
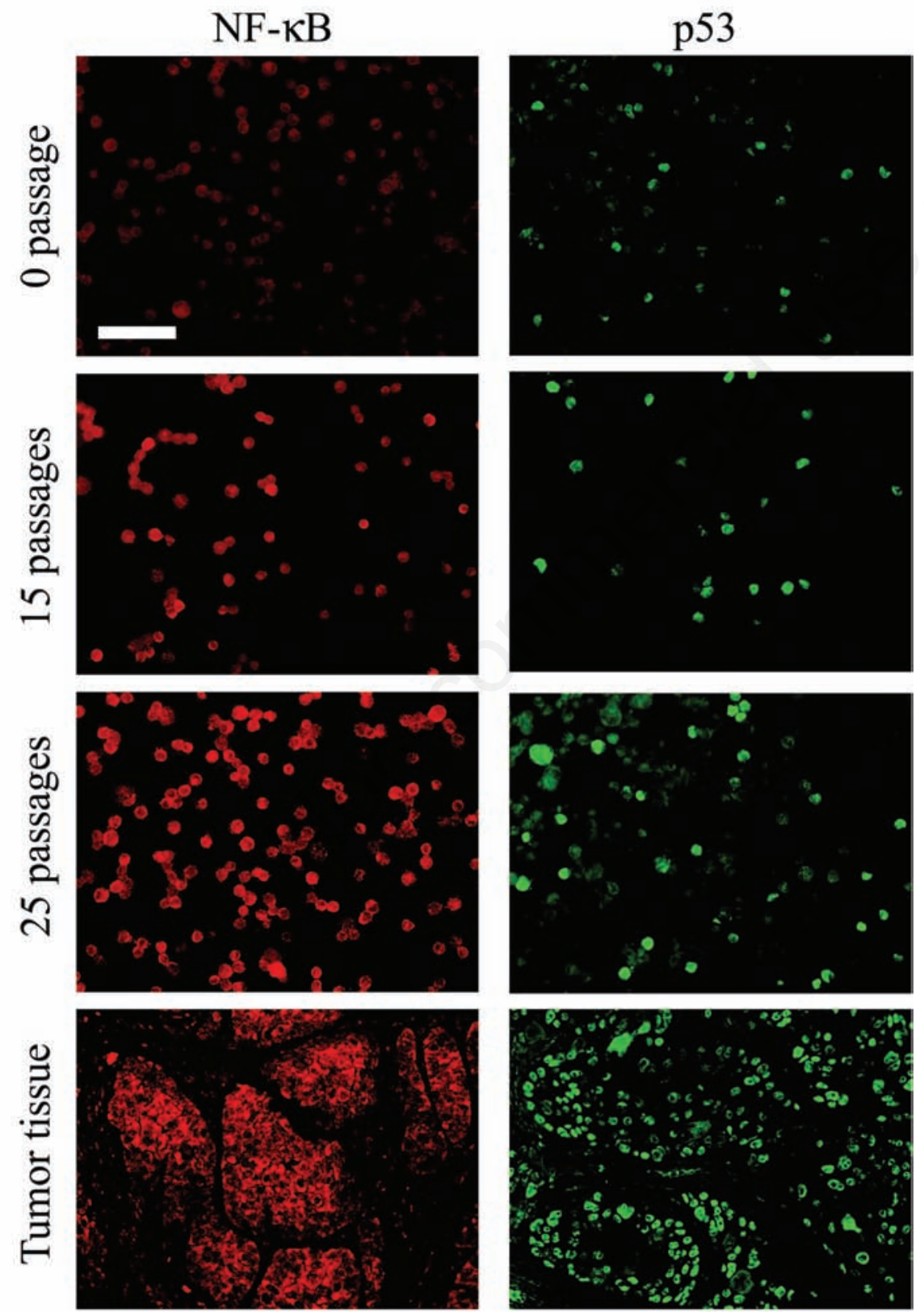

Figure 8. NF- $\mathrm{KB}$ and $\mathrm{p} 53$ expression in arsenic-treated cells and Xenograft tumor tissues. $\mathrm{NF}-\mathrm{KB}$ and $\mathrm{p} 53$ immunoreactivity were observed primarily in the nucleus of some of $\mathrm{HaCaT}$ cell and tumor cells in the Xenograft tumor. Scale bar: $100 \mu \mathrm{m}$. is known that NF- $\kappa \mathrm{B}$ activation can initiate and accelerate tumorigenesis, and that NF$\kappa \mathrm{B}$ inhibition blocks tumor promoter-induced cell transformation. ${ }^{57}$ In HaCaT cells exposed to a low level of arsenite, NF- $\kappa$ B was shown to inhibit 553 function by mot- 2 , an effect that facilitates p53mediated DNA repair and prevents arsenic-induced malignant transformation. ${ }^{55}$ In the present study, the activations of CD44v6 expression by arsenic occurred after the activation of the transcription factor NF$\kappa \mathrm{B}$ and changes in $\mathrm{p} 53$ gene expression. In addition to changes in gene expression, arsenic caused major cell cycle changes and uncontrolled cell growth; and experiments with $\mathrm{HaCaT}$ cells transplanted from tumor tissue taken from nude mice showed a high expression of CD44v6, NF- $\mathrm{KB}$ and p53. Our research also determined that $\mathrm{CD} 44 \mathrm{v} 6$ can serve as a biomaker of arsenic-induced neoplastic transformation in human skin cells, and that activation of CD44v6 through a NF$\kappa \mathrm{B}$-dependent signaling pathway may underlie arsenic-induced malignant transformation in human skin lesions.

\section{References}

1. International Agency for Research on Cancer. Some drinking-water disinfectants and contaminants, including arsenci, Monographs on chloramine, chloral and chloral hydrate, dichloroacetic acid and 3-chloro-4-(dichloromethly)-5hydoroxy-2(5H)-furanone. IARC Monographs on the Evaluation of Carcinogenic Risks to Humans, 2004, p. 269-477.

2. Alonso FT, Garmendia ML, Bogado ME. Increased skin cancer mortality in Chile beyond the effect of ageing: Temporal analysis 1990 to 2005. Acta Derm Venereol 2010;90:141-6.

3. Celik I, Gallicchio L, Boyd K, Lam TK, Matanoski G, Tao X, et al. Arsenic in drinking water and lung cancer: a systematic review. Environ Res 2008;108:48-55.

4. Chen CL, Chiou HY, Hsu LI, Hsueh YM, Wu MM, Wang YH, et al. Arsenic in drinking water and risk of urinary tract cancer: a follow-up study from northeastern Taiwan. Cancer Epidemiol Biomarkers Prev 2010; 19:101-10.

5. Meliker JR, Slotnick MJ, AvRuskin GA, Schottenfeld D, Jacquez GM, Wilson ML, et al. Lifetime exposure to arsenic in drinking water and bladder cancer: a population-based case-control study in Michigan, USA. Cancer Causes Control 2010;21:745-57.

6. Morales KH, Ryan L, Kuo TL, Wu MM, Chen CJ. Risk of internal cancers from arsenic in drinking water. Environ Health Perspect 2000;108:655-61. 
7. Smith AH, Hopenhayn-Rich C, Bates MN, Goeden HM, Hertz-Picciotto I, Duggan $\mathrm{HM}$, et al. Cancer risks from arsenic in drinking water. Environ Health Perspect 1992; 97:259-67.

8. Rossman TG, Uddin AN, Burns FJ, Bosland MC. Arsenite is a cocarcinogen with solar ultraviolet radiation for mouse skin: an animal model for arsenic carcinogenesis. Toxicol Appl Pharmacol 2001;176:64-71.

9. Rossman TG, Uddin AN, Burns FJ, Bosland MC. Arsenite cocarcinogenesis: an animal model derived from genetic toxicology studies. Environ Health Perspect 2002;110:749-52.

10. Lobo NA, Shimono Y, Qian D, Clarke MF. The biology of cancer stem cells. Annu Rev Cell Dev Biol 2007;23:675-99.

11. 0'Brien CA, Kreso A, Jamieson CH. Cancer stem cells and self-renewal. Clin Cancer Res 2010;16:3113-20.

12. Pardal R, Clarke MF, Morrison SJ. Applying the principles of stem-cell biology to cancer. Nat Rev Cancer 2003;3:895902.

13. Polyak K, Hahn WC. Roots and stems: stem cells in cancer. Nat Med 2006;12:296-300.

14. Visvader JE, Lindeman GJ. Cancer stem cells in solid tumours: accumulating evidence and unresolved questions. Nat Rev Cancer 2008;8:755-68.

15. Pilloni L, Bianco P, Difelice E, Cabras S, Castellanos ME, Atzori L, et al. The usefulness of c-Kit in the immunohistochemical assessment of melanocytic lesions. Eur J Histochem 2011;55:e20.

16. Bujas T, Marusic Z, Peric Balja M, Mijic A, Kruslin B, Tomas D. MAGE-A3/4 and NYESO-1 antigens expression in metastatic esophageal squamous cell carcinoma. Eur J Histochem 2011;55:e7.

17. Nemolato S, Cabras T, Fanari MU, Cau F, Fraschini M, Manconi B, et al. Thymosin beta 4 expression in normal skin, colon mucosa and in tumor infiltrating mast cells. Eur J Histochem 2012;54:e3.

18. Bomken S, Fiser K, Heidenreich 0, Vormoor J. Understanding the cancer stem cell. Br J Cancer 2010;103:439-45.

19. Reya T, Morrison SJ, Clarke MF, Weissman IL. Stem cells, cancer, and cancer stem cells. Nature 2001;414:105-11.

20. Omran OM, Ata HS. CD44s and CD44v6 in diagnosis and prognosis of human bladder cancer. Ultrastruct Pathol 2012;36:145-52.

21. Gunthert U, Hofmann M, Rudy W, Reber S, Zoller M, Haussmann I, et al. A new variant of glycoprotein CD44 confers metastatic potential to rat carcinoma cells. Cell 1991; 65:13-24.

22. Zhou ZJ, Dai Z, Zhou SL, Fu XT, Zhao YM, Shi YH, et al. Overexpression of HnRNP
A1 promotes tumor invasion through regulating CD44v6 and indicates poor prognosis for hepatocellular carcinoma. Int $\mathrm{J}$ Cancer 2013;132:1080-9. Epub 2012 Aug 7.

23. Gun BD, Bahadir B, Bektas S, Barut F, Yurdakan G, Kandemir NO, et al. Clinicopathological significance of fascin and CD44v6 expression in endometrioid carcinoma. Diagn Pathol 2012;7:80.

24. Turley EA, Noble PW, Bourguignon LY. Signaling properties of hyaluronan receptors. J Biol Chem 2002;277:4589-92.

25. Welsh CF, Zhu D, Bourguignon LY. Interaction of CD44 variant isoforms with hyaluronic acid and the cytoskeleton in human prostate cancer cells. J Cell Physiol 1995;164:605-12.

26. Hong SC, Song JY, Lee JK, Lee NW, Kim $\mathrm{SH}$, Yeom BW, et al. Significance of CD44v6 expression in gynecologic malignancies. J Obstet Gynaecol Res 2006 32:379-86.

27. Mima K, Okabe H, Ishimoto T, Hayashi $\mathrm{H}$, Nakagawa S, Kuroki H, et al. The expression levels of CD44v6 are correlated with the invasiveness of hepatocellular carcinoma in vitro, but do not appear to be clinically significant. Oncol Lett 2012;3: 1047-51.

28. Dommann SN, Ziegler T, DommannSchener CC, Meyer J, Panizzon R, Burg G. CD44v6 is a marker for systemic spread in cutaneous T-cell lymphomas. A comparative study between nodal and cutaneous lymphomas. J Cutan Pathol 1995; 22:407-12.

29. Bode AM, Dong Z. The paradox of arsenic: molecular mechanisms of cell transformation and chemotherapeutic effects Crit Rev Oncol Hematol 2002;42:5-24.

30. Du CW, Wen BG, Li DR, Peng X, Hong CQ, Chen JY, et al. Arsenic trioxide reduces the invasive and metastatic properties of nasopharyngeal carcinoma cells in vitro. Braz J Med Biol Res 2006;39:677-85.

31. Du Y, Zhang D, Liu H, Lai R. Thermochemotherapy effect of nanosized As203/ Fe304 complex on experimental mouse tumors and its influence on the expression of CD44v6, VEGF-C and MMP-9. BMC Biotechnol 2009;9:84.

32. Lin TH, Kuo HC, Chou FP, Lu FJ. Berberine enhances inhibition of glioma tumor cell migration and invasiveness mediated by arsenic trioxide. BMC Cancer 2008;8:58.

33. Yu J, Qian H, Li Y, Wang Y, Zhang X, Liang $\mathrm{X}$, et al. Arsenic trioxide (As203) reduces the invasive and metastatic properties of cervical cancer cells in vitro and in vivo. Gynecol Oncol 2007;106:400-6.

34. Bodwell JE, Kingsley LA, Hamilton JW. Arsenic at very low concentrations alters glucocorticoid receptor (GR)-mediated gene activation but not GR-mediated gene repression: complex dose-response effects are closely correlated with levels of activated GR and require a functional GR DNA binding domain. Chem Res Toxicol 2004; 17:1064-76.

35. He XQ, Chen R, Yang P, Li AP, Zhou JW, Liu QZ. Biphasic effect of arsenite on cell proliferation and apoptosis is associated with the activation of JNK and ERK1/2 in human embryo lung fibroblast cells. Toxicol Appl Pharmacol 2007;220:18-24.

36. Shen S, Lee J, Weinfeld $M$, Le XC. Attenuation of DNA damage-induced p53 expression by arsenic: a possible mechanism for arsenic co-carcinogenesis. Mol Carcinog 2008;47:508-18.

37. Wen G, Calaf GM, Partridge MA, Echiburu-Chau C, Zhao Y, Huang S, et al. Neoplastic transformation of human small airway epithelial cells induced by arsenic. Mol Med 2008;14:2-10.

38. Pi J, Diwan BA, Sun Y, Liu J, Qu W, He Y, et al. Arsenic-induced malignant transformation of human keratinocytes: involvement of Nrf2. Free Radic Biol Med 2008;45:651-8.

39. Damm S, Koefinger P, Stefan M, Wels C, Mehes G, Richtig E, et al. HGF-promoted motility in primary human melanocytes depends on CD44v6 regulated via NFkappa B, Egr-1, and C/EBP-beta. J Invest Dermatol 2010;130:1893-903.

40. Boukamp P, Petrussevska RT, Breitkreutz D, Hornung J, Markham A, Fusenig NE. Normal keratinization in a spontaneously immortalized aneuploid human keratinocyte cell line. J Cell Biol 1988;106: 761-71.

41. Pinlaor S, Ma N, Hiraku Y, Yongvanit P, Semba R, Oikawa S, et al. Repeated infection with Opisthorchis viverrini induces accumulation of 8-nitroguanine and 8oxo-7,8-dihydro-2'-deoxyguanine in the bile duct of hamsters via inducible nitric oxide synthase. Carcinogenesis 2004; 25:1535-42.

42. Huang C, Ke Q, Costa M, Shi X. Molecular mechanisms of arsenic carcinogenesis. Mol Cell Biochem 2004;255:57-66.

43. Germolec DR, Spalding J, Boorman GA, Wilmer JL, Yoshida T, Simeonova PP, et al. Arsenic can mediate skin neoplasia by chronic stimulation of keratinocytederived growth factors. Mutat Res 1997; 386:209-18.

44. Kitchin KT. Recent advances in arsenic carcinogenesis: modes of action, animal model systems, and methylated arsenic metabolites. Toxicol Appl Pharmacol $2001 ; 172: 249-61$.

45. Tokar EJ, Diwan BA, Waalkes MP. Arsenic exposure transforms human epithelial stem/progenitor cells into a cancer stemlike phenotype. Environ Health Perspect 
2010;118:108-15.

46. Liu YJ, Yan PS, Li J, Jia JF. Expression and significance of CD44s, CD44v6, and nm23 mRNA in human cancer. World $\mathrm{J}$ Gastroenterol 2005;11:6601-6.

47. Herrlich P, Pals S, Ponta H. CD44 in colon cancer. Eur J Cancer 1995;31A:1110-2.

48. Stauder R, Eisterer W, Thaler J, Gunthert U. CD44 variant isoforms in nonHodgkin's lymphoma: a new independent prognostic factor. Blood 1995;85:2885-99.

49. Halazonetis TD, Gorgoulis VG, Bartek J. An oncogene-induced DNA damage model for cancer development. Science 2008;319: 1352-5.

50. Protrka Z, Arsenijevic S, Dimitrijevic A, Mitrovic S, Stankovic V, Milosavljevic M, et al. Co-overexpression of bcl-2 and cmyc in uterine cervix carcinomas and premalignant lesions. Eur J Histochem 2011;55:e8.

51. Konstantakou EG, Voutsinas GE, Karkoulis PK, Aravantinos G, Margaritis LH, Stravopodis DJ. Human bladder cancer cells undergo cisplatin-induced apoptosis that is associated with p53-dependent and p53-independent responses. Int $\mathrm{J}$ Oncol 2009;35:401-16.

52. Lim do Y, Park JH. Induction of p53 contributes to apoptosis of HCT-116 human colon cancer cells induced by the dietary compound fisetin. Am J Physiol Gastrointest Liver Physiol 2009;296:G1060-8.

53. Aylon Y, Oren M. Living with p53, dying of p53. Cell 2007;130:597-600.

54. Kastan MB. Wild-type p53: tumors can't stand it. Cell 2007;128:837-40.

55. Bukholm IK, Nesland JM. Protein expression of p53, p21 (WAF1/CIP1), bcl-2, Bax, cyclin D1 and pRb in human colon carcinomas. Virchows Arch 2000;436:224-8.

56. Pietsch EC, Sykes SM, McMahon SB, Murphy ME. The p53 family and programmed cell death. Oncogene 2008;27: 6507-21.

57. Li JJ, Oberley LW. Overexpression of manganese-containing superoxide dismutase confers resistance to the cytotoxicity of tumor necrosis factor alpha and/or hyperthermia. Cancer Res 1997;57:1991-8. 